\title{
Responsible Use of Medicinal Plants for Cosmetics
}

\author{
Barbara M. Schmidt ${ }^{1}$ \\ L'Oréal Research and Innovation, 111 Terminal Avenue, Clark, NJ 07066
}

Additional index words. Traditional Chinese Medicine, wild crafting, sustainability, organic, palm oil, biodiversity

\begin{abstract}
Medicinal plant extracts are widely used as active ingredients in cosmetics. Plant material can come from a variety of sources, including commercial production horticulture and wild harvest in developing countries. Sustainably produced plant material does not threaten biodiversity, release pollution, compete with the food supply, or exploit local people. International treaties like the Rio Convention on Biological Diversity and CITES (Washington Convention) and regulations like Good Agricultural Practices (GAP) have been established to guide sustainable sourcing and production of plant material. Non-profit organizations like the Round Table Sustainable Palm Oil have been organized to create sustainability standards. Once a reliable and sustainable supply chain has been established, cosmetic companies must be aware of regulations set by the U.S. Food and Drug Administration, U.S. Department of Agriculture, and international regulatory agencies that guide the marketing of cosmetics with medicinal plant ingredients. Efficacy claims should be supported with evidence and cannot state that the product treats medical conditions. In the end, responsibly sourced medicinal plants can bring economic benefit to producers, processors, and marketers.
\end{abstract}

Medicinal plants are widely used as bioactive raw materials for cosmetics and personal care products. The source of medicinal plants varies greatly, from wild crafting traditional medicinal plants in China to modern horticultural production systems in North America and Europe. Although some growers make their own extracts, others use contract manufacturers that can be found throughout the world. Regardless of the source material or extraction process, quality control issues like contamination, reproducibility, standardization, toxicity, and protection of actives must be addressed. Additionally, sustainability of the supply chain is an important issue, not only to assure a continuous supply of raw material, but to be sure the supply chain is not harming the environment or society (Philippe et al., 2012).

The purpose of this review is to provide insight into the supply chain and sustainable production of medicinal plants for use in cosmetics, especially for those unfamiliar with the industry. Growers and researchers may be familiar with requirements and regulations for producing plant material for the food and nutrition industries. However, they may not be aware of the unique regulatory environment for cosmetics or what is considered sustainable production or responsible use of medicinal plants for cosmetics.

\section{OVERVIEW OF THE PERSONAL CARE INDUSTRY}

The personal care industry creates cosmetic products used for beautification and hygiene products used for cleansing. The terms "cosmetics," "beauty products," and

Received for publication 12 Dec. 2011. Accepted for publication 15 Mar. 2012.

This paper was part of the colloquium "Research Highlights and Commercial Application of Medicinal Plants" held 27 Sept. 2011 at the ASHS Conference, Waikoloa, HI, and sponsored by the Working Group of Asian Horticulture (WGAH) and the Association of Horticulturists of Indian Origin (AHIO).

${ }^{1}$ To whom reprint requests should be addressed; e-mail bschmidt@rd.us.loreal.com. "personal care products" are often used interchangeably despite their subtle differences. The Women's Wear Daily Beauty Inc. Top 100 ranks the world's largest beauty manufacturers. For their purposes, beauty products include fragrance, makeup, skin care, sun care, hair care, deodorant, cellulite, and shaving products, but not bar soaps, razors, toothpastes, foods, diet foods, medicines, vitamins, or detergents. In 2011, the top 100 beauty companies generated $\$ 176.18$ billion of sales (Weil, 2011). The top 10 beauty companies worldwide (ranked by 2010 revenues) are L'Oreal (\$25.9 billion), Procter \& Gamble ( $\$ 19.6$ billion), Unilever ( $\$ 17.0$ billion), Estee Lauder Cos. ( $\$ 8.3$ billion), Shiseido (\$7.8 billion), Avon Products ( $\$ 7.7$ billion), Beiersdorf ( $\$ 6.7$ billion), Kao Corporation ( $\$ 5.8$ billion), Johnson \& Johnson ( $\$ 5.7$ billion), and Chanel ( $\$ 4.4$ billion).

Just like the pharmaceutical, food, and nutrition industries, the cosmetics industry employs scientists from the discovery stage to product development. In the discovery stage, many different strategies are used including monitoring consumer trends; attending conferences and trade shows; evaluating scientific advances in other industries for possible technology transfer opportunities; monitoring scientific publications and press reports; making research collaborations with universities, institutes, and biotechnology companies; and internal discovery research to create proprietary molecules, technology, or evaluation methods. In the area of horticulture and plant science, cosmetics companies often make external collaborations to advance their own knowledge in this area or to bring in new technology, new natural product molecules, or higher quality plant-based raw materials. There are several examples of cosmetics companies partnering with universities, institutes, or non-governmental organizations to secure supply chains of raw materials, gain certification of their raw materials, or to find higher quality, more sustainable plant-based raw materials (Box 1). Through these partnerships, the companies not only increase their scientific knowledge and acquire innovative raw materials, but they contribute to society in a positive way.

\section{SUPPLY AND SOURCE OF MEDICINAL PLANT MATERIAL}

Cosmetics companies work with a wide range of suppliers to obtain botanical raw materials, from large global chemical companies with a range of ingredients to small local companies offering a few specialized extracts. These suppliers purchase plant biomass from a wide array of sources, which also range from large to small scale. The plant material may be wild-crafted, produced by conventional horticultural methods (e.g., field or greenhouse), or produced through biotechnology (e.g., microalgae, hydroponics, fermentation, tissue culture). In the global supply chain from plant material to cosmetics ingredient, the source of the biomass is not always evident.

Rio Convention on Biological Diversity. During the 1992 Earth Summit in Rio de Janeiro, three conventions were held, including The Convention on Biological Diversity (CBD) (United Nations, 1992). The CBD is an international legally binding treaty with three main goals: conservation of biodiversity; sustainable use of biodiversity; and the fair and equitable sharing of the benefits arising from the use of genetic resources. The Nagoya Protocol on Access to Genetic Resources and the Fair and Equitable Sharing of Benefits Arising from their Utilization (Secretariat of the Convention on Biological Diversity, 2011) is a supplementary agreement to the Rio Convention on Biological Diversity that addresses benefits arising from the commercial use of genetic resources. This protocol has significant implications for using medicinal plants in the cosmetics industry.

During the discovery phase for new cosmetic active ingredients, traditional knowledge from indigenous people or local communities on the bioactivity of genetic resources, (plant, animal, or microorganisms) may be provided to researchers. This knowledge may be provided to industrial scientists directly through international research collaboration agreements or indirectly through collaborations with third-party CROs or university research laboratories. In any case, if a company wishes to access a genetic resource in a foreign country, 
it must first request the informed consent of the country where the resource is located. The terms and conditions of access and use of the resource must be negotiated. Benefit sharing is often required as part of the agreement, which may include royalties generated from commercialization of a product. Intellectual property is typically shared between the user and provider of the genetic resource.

Production and exports. According to the Food and Agriculture Organization (FAO) of the United Nations (2004), the developing world produces and exports most of the global supply of medicinal plant raw materials. Although domestic trade in these countries is not well documented, the FAO maintains statistics on medicinal plant exports and imports. China is the largest exporter of medicinal plants followed by India (FAO of the United Nations, 2004). China also plants the most hectares of medicinal plants, followed by the US (FAO of the United Nations, 2004). Other major producing and exporting countries include Brazil, Thailand, Chile, and the Republic of Korea (FAO of the United Nations, 2004). The supply chain for medicinal plants can be very long and complicated with producers, processors, and their buyers located in different countries. Often, there are dealers, distributors, and wholesalers involved, creating a complex trail of players. Exports may be a finished product like an extract or essential oil or it could be a commodity like whole or ground dry plant parts. To avoid stringent regulations of pharmaceuticals in the European Union and the United States, developing countries prefer to export commodities instead of finished medicinal products. However, sometimes even the commodities are not competitive on the global market as a result of lack of access to technology, limited knowledge of plant biology, poor harvesting practices, inferior varieties, inefficient processing, no quality control protocols, no process or product development, and lack of knowledge of local and international markets (De Silva, 1997; FAO of the United Nations, 2004). This is especially true for plant material produced in the least developed countries.

Wild-crafting. Harvesting plants from the wild, or wild-crafting, is still popular for many medicinal herbs, especially traditional medicine herbs from Traditional Chinese Medicine (TCM) or Ayurvedic medicine. However, overharvesting can reduce plant populations to the point where the species biodiversity is threatened. Some species have been harvested close to extinction, like Nardostachys jatamansi and Aconitum spp. (FAO of the United Nations, 2004). Some regulate wild-crafting, with the exception of India, Bulgaria, and Nepal (FAO of the United Nations, 2004). Guidelines for GAP of Medicinal Plants and Animals have been established by the World Health Organization (WHO) (Fong et al., 2003) and governments worldwide, including China (State Drug Administration, P.R. China, 2002). According to China's GAP guidelines, standardized management and quality control policies should be adopted to regulate and control the exploitation of raw materials to achieve "maximum sustainable yield," protecting Chinese medicinal resources toward a sustainable use. It recognizes the traditional belief that to have maximum potency, a medicinal herb should be harvested from the region of origin (Shi et al., 2011). This is also known as the geo-authentic concept. GAP guidelines define geo-authentic medicinal materials as authentic traditional medicinal materials of high quality, which have special germplasm, places of origin, and require special production techniques and processing methods (State Drug Administration, P.R. China, 2002). This does not imply that authentic, high-quality traditional herbs must be wild-crafted. Instead, it encourages special production techniques to sustainably produce the herb in the region of origin. The WHO provides guidelines for collection of medicinal plants either on a small or large scale (Fong et al., 2003). According to these guidelines, collection practices should ensure the long-term survival of wild populations and their associated habitats. Management plans for collection should provide a framework for setting sustainable harvest levels and describe appropriate collection practices that are suitable for each medicinal plant species. For example, if roots are to be collected, the main roots should not be cut or dug up, and severing the taproot of trees and bushes should be avoided.

In the United States, overharvest and deforestation has led to a decline in American ginseng (Panax quinquefolius L.) populations. The remaining plants have a patchy distribution with poor gene flow between populations and a significant difference in levels of ginsenosides. A recent study (Assinewe et al., 2003) showed no statistical difference in mean ginsenoside content between wild and cultivated $P$. quinquefolius roots at 4 years of age, suggesting there is no phytochemical justification for wild crafting. Another study (Pereira et al., 2003) developed a successful tissue culture technique to propagate Catuaba (Anemopaegma arvense), a Brazilian medicinal plant endangered from overharvest and deforestation. This research provides a viable method to cultivate a medicinal herb in which all commercially available extracts come from wild-crafting. Slowly, GAP initiatives along with research that demonstrates viable alternatives to wild-crafting will transform the production landscape for traditional medicinal herbs.

Conventional production. Many medicinal plant extracts used in cosmetics come from plant material that was grown using conventional horticultural methods such as field or greenhouse production. Argentina, China, Hungary, India, Poland, and Spain are countries that produce large amounts of medicinal herbs using conventional horticulture production (FAO of the United Nations, 2004). Field cultivation is optimal for largescale production; however, several factors must be considered to ensure uniformity, which can better be achieved in the controlled environment of a greenhouse or growth chamber. First, starting seed material must be authenticated. There are many laboratories in North America and Europe providing seed testing services that include polymerase chain reaction-based techniques, looking for markers specific to the desired species (Mak and Mok, 2011). In countries where this technology is not available, a seed can be authenticated using microscopy to evaluate morphological traits. Variations in soil, fertility, moisture, temperature, irradiance, pests, disease, and herbivory can cause substantial variability in the secondary metabolism of plants within a field and from season to season. These environmental variations can better be controlled in a greenhouse or growth chambers. Certainly, advanced systems have been engineered for a high level of control for crop uniformity (Thongbaia et al., 2010). However, these systems can be expensive as a result of high energy demand and may not be economical when dealing with lower-value medicinal crops. No matter which production system is used, the resulting plant material must be tested for quality and reproducibility. Typically, downstream processing of the extract by concentration, filtration, separation, column chromatography, etc., can be used to mitigate variations in secondary metabolism; however, this is not always the case. Therefore, if production of a specific natural product is required, controlled environments found in greenhouses or growth chambers where elicitation methods can be used will produce more uniform results.

Biotechnology. To achieve even higher levels of uniformity and yields than traditional field or greenhouse production methods can deliver, biotechnology methods have been developed including fermentation or bioreactor production of genetically modified organisms, hydroponic systems where hairy root cultures exude medicinal compounds, and photobioreactors growing microalgae that have been modified to produce desirable primary or secondary metabolites. These systems typically produce pure molecules, or purified extracts, as a result of the economics of creating/selecting the organism and operational costs of the production system. One benefit of these systems is that they can be used as a method to preserve biodiversity. Through biotechnology, plants that are endangered or otherwise unavailable through conventional production or wild-crafting may be commercialized as extracts or new molecules. In fermentation systems, substantial amounts of sugars are required as a carbon source. According to the World Bank (2011b), currently the most widely grown and economical sugars in the Western hemisphere come from corn, sugar cane, sugar beets, or sorghum. Therefore, many large fermentation manufacturers are located close to these production regions. During 2010-2011, 28\% of the U.S. corn crop went to biofuel production instead of food/feed (World Bank, 2011c). This is equal to $\approx 11 \%$ of the global production of corn, a magnitude comparable to all the global corn exports for this year. Most scientists and economists agree that the U.S. 
mandate to increase biofuels production has helped to drive up the cost of food worldwide (Timilsina and Shrestha, 2010). The World Bank estimates the 2010-2011 grain price increases may have pushed as many as 44 million people into poverty (World Bank, 2011a). They predict continued demand for agricultural commodities such as sugar, corn, and oil seeds because biofuel feedstocks would significantly increase their prices in 2020, which will continue to affect the food supply (Timilsina et al., 2010). Initiatives to use agricultural wastes as feedstocks are underway; however, they are not yet economical (Zinoviev et al., 2010). Certainly commercializing agricultural waste and other nonfood crop feedstocks will have a positive impact on the sustainability of fermentation systems for biofuels and bioproducts.

\section{SUSTAINABILITY}

Nearly every corporate web page includes a section on sustainability or a sustainability report, often including goals to reduce energy consumption, recycle waste, and reduce greenhouse gas emissions, to name a few. As already mentioned in this article, there are many sustainability issues to consider when sourcing medicinal plants for use in a cosmetic product. However, what is "sustainability" and how can it be measured? One tool used to measure sustainability is a life cycle assessment (LCA) (Tabone et al., 2010). A LCA can be used to determine the environmental impacts from all stages of a product's life, also called a "cradle-to-grave" assessment. This type of assessment analyzes the resources used from extraction/creation of raw materials through product development, manufacturing, distribution, use, and, finally, disposal or recycling. For cosmetics, the formula (e.g., skin cream, fragrance, mascara) comes to mind as the product under consideration. However, packaging is often an equal or greater use of resources than the formula itself. For the purposes of this review, raw material sustainability will be addressed, because it is most relevant to the medicinal plant industry.

Sustainability is a continuum rather than a binary issue. When someone claims a raw material is "sustainable," the question must be asked: "compared with what?" Often, the terms "renewable" and "sustainable" are used interchangeably; however, just because a resource is renewable does not mean it is sustainable for long-term production. One example of this continuum is palm oil (Box 1, Case 2). Palm oil is a renewable resource produced from the fruit pulp of the oil palm (Elaeis spp.); palm kernel oil is produced from the kernel. Both products are widely used in the cosmetics and food industries along with chemical derivatives that use palm oil as a starting material. Palm oil is produced on plantations mainly in Africa and Southeast Asia and is a valuable economic crop for these regions, providing a source of employment, infrastructure, and oil for cooking and fuel. Unfortunately, palm oil plantations have caused environmental issues (Fitzherbert et al., 2008). Large areas of high biodiversity forests have been cleared for new plantations, reducing the habitat of species already threatened with extinction and releasing $\mathrm{CO}_{2}$ into the atmosphere that had been previously sequestered in the forest and peat bogs (Verhoeven and Setter, 2010). In addition, the plantations have a history of land right violations and mistreatment of their workers (RSPO Executive Board, 2007a). All of this poses an ethical issue for users of palm oil. In response, the Roundtable on Sustainable Palm Oil (RSPO) was formed to tackle these issues. RSPO members include palm oil users, processors, and producers. They have worked together to establish guidelines and a certification program for sustainably produced palm oil (RSPO Executive Board, 2007b). Some of the principles of these guidelines include:

- Commitment to transparency;

- Compliance with laws and regulations;

- Commitment to long-term economic and financial viability;

- Use of appropriate best practices by growers and millers;

- Environmental responsibility and conservation of natural resources and biodiversity;

- Responsible consideration of employees and of individuals and communities affected by growers and mills; and

- Responsible development of new plantings.

Auditors make sure the producers and processors of palm oil comply with the guidelines before they can receive sustainable palm oil certification. Today, many companies can claim $100 \%$ of the palm oil used in their products is certified sustainable.

A LCA of conventional palm oil production (Achten et al., 2010) showed that, as a biofuel, palm oil has a lower global warming and acidification potential than fossil fuels. However, eutrophication from palm oil mill runoff and deforestation from new palm plantations neutralizes the aforementioned benefits for 45 to 53 years. In addition, treatment of effluent to reduce eutrophication further reduces savings in global warming potential. This LCA was specifically designed for conventionally grown palm oil as biofuel and not as a raw material for cosmetic products. However, the message is clear: renewable does not necessarily equal sustainable.

Palm oil provides a classic example of the continuum of sustainability, but it is not a medicinal herb, which is typically grown at a much smaller scale. Still, many of the issues outlined in the RSPO guidelines and the WHO GAP guidelines are relevant for medicinal plant production. Before a medicinal plant producer decides to supply the cosmetics industry, they should consider: will production of this medicinal herb for cosmetics show respect for the environment (protecting biodiversity and natural resources while limiting climate change and pollution) and for society (fair trade, respect for landowners and local communities)? If not, production methods must be modified to address these issues. In addition, producers must plan for success. If demand increases significantly for their medicinal plants, will the scaled-up production over many years be sustainable? In the end, the whole process must still be economical. Therefore, any changes made to increase the sustainability of medicinal plant production should be weighed against the effect of these changes on the price of the final product. Consumers will often pay a premium price for sustainable materials, but there is certainly a limit to what the market will allow.

\section{CURRENT MARKET TRENDS}

Innovation in the area of medicinal plants for use in cosmetic products is largely consumer-driven. Today's consumer demands products that are safe, natural, and sustainable but still effective and economical. Many would like to see synthetic, petroleum-based ingredients replaced with ingredients of plant origin; however, they are not often willing to sacrifice quality or functionality for this principle. The cosmetics industry moves quickly to follow consumer trends, relatively unencumbered in the U.S. by Food and Drug Administration (FDA) regulation compared with the pharmaceutical industry. Although traditional ingredients like aloe and rosewater can still be found in many products, most companies are competing for market share by introducing new molecules derived from nature and standardized extracts like açai berry, green tea, or microalgae, to name a few. The International Nomenclature for Cosmetic Ingredients (INCI) system contains over 800 new ingredients listed every year; the 2011 edition contains 91,620 INCI names including 42,680 trade names and over 50,000 Chinese traditions. Approximately one-third of these ingredients are classified as "botanical extracts"; however, many of these ingredients are various formulations of the same plant material. Raw material companies unveil new formulations of botanical extracts in their catalogs and at trade shows. In 2011, two cosmetic industry trade shows, in-cosmetics (Milan, Italy) and the supplier's day showcase (New Jersey), featured "natural" and "sustainable" materials as their theme and included extracts like açai (Euterpe L.), brazil nut (Bertholletia excelsa Humb. \& Bonpl.), golden root (Rhodiola rosea), sea buckthorn (Hippophae rhamnoides), blue honeysuckle berry (Lonicera caerulea), ashwagandha (Withania somnifera Dunal), licorice (Glycyrrhiza glabra L.), lotus (Nelumbo nucifera Gaertn.), and indian sarsaparilla (Hemidesmus indicus L. R.Br.). Another recent trend in Western cosmetics is ingredients from TCM (Table 1) or Ayurvedic Medicine, which may include extracts or compounds from plant, fungi, or animal origin.

\section{INDUSTRY REGULATIONS}

Compared with the pharmaceutical industry in the United States, the FDA does 
Table 1. Examples of Traditional Chinese Medicines used in cosmetics compiled from cosmetic ingredient supplier catalogs.

\begin{tabular}{|c|c|c|c|}
\hline Botanical name & Family & Common name & Plant part \\
\hline$\overline{\text { Achyranthes bidentata }}$ & Amaranthaceae & nui xi & Root \\
\hline Adenophora stricta & Campanulaceae & sha shen & Root \\
\hline Angelica dahurica & Apiaceae & bai zhi & Root \\
\hline Angelica sinensis & Apiaceae & dong quai & Root \\
\hline Asarum sieboldii & Aristolochiaceae & xi xin, chinese wild ginger & Whole plant \\
\hline Asarum heterotropiodes & Aristolochiaceae & xi xin, chinese wild ginger & Whole plant \\
\hline Astragalus propinquus & Fabaceae & huáng qí & Root \\
\hline Platycladus orientalis & Cupressaceae & chinese arborvitae, biota & Shoot \\
\hline Bletilla striata & Orchidaceae & chinese ground orchid & Rhizome \\
\hline Bupleurum falcatum & Apiaceae & chinese thoroughwax & Root \\
\hline Calendula officinalis & Asteraceae & marigold & Flower, leaf \\
\hline Camellia sinensis & Theaceae & tea & Leaf \\
\hline Centella asiatica & Mackinlayaceae & gotu kola & Leaf \\
\hline Chrysanthemum indicum & Asteraceae & chrysanthemum & Stem, flower \\
\hline Cimicifuga dahurica & Ranunculaceae & xing an sheng ma, cohosh & Root \\
\hline Coptis chinensis & Ranunculaceae & goldthread & Rhizome \\
\hline Eucommia ulmoides & Eucommiaceae & dùzhòng & Bark \\
\hline Evodia rutaecarpa & Rutaceae & wu zhu yu & Fruit \\
\hline Forsythia suspensa & Oleaceae & forsythia & Fruit \\
\hline Ganoderma lucidum & Ganodermataceae & reishi mushroom & [Mushroom] \\
\hline Ginkgo Biloba & Ginkgoaceae & ginkgo & Leaf \\
\hline Glycyrrhiza glabra & Fabaceae & european licorice & Root \\
\hline Glycyrrhiza uralensis & Fabaceae & chinese licorice & Root \\
\hline Hipphophae rhamnoides & Elaeagnaceae & sea buckthorn & Fruit \\
\hline Saccharina japonica & Laminariaceae & brown algae & Whole plant \\
\hline Lavendula angustifolia & Lamiaceae & common lavender & Flower, leaf \\
\hline Lentinus edodes & Marasmiaceae & shiitake mushroom & [Mushroom] \\
\hline Leonurus japonicus & Lamiaceae & chinese motherwort & Fruit \\
\hline Ligusticum wallichii & Apiaceae & chuānxiōng & Root \\
\hline Ligusticum sinense & Apiaceae & gao ben & Root \\
\hline Ligustrum lucidum & Apiaceae & chinese privet & Root \\
\hline Lycium chinense & Solanaceae & wolfberry, goji berry & Fruit \\
\hline Magnolia biondii & Magnoliaceae & chinese willowleaf magnolia & Bark \\
\hline Magnolia officinalis & Magnoliaceae & houpu magnolia & Flower \\
\hline Matricaria reticulata & Asteraceae & common chamomile & Flower, seed \\
\hline Morus alba & Moraceae & mulberry & Fruit \\
\hline Nelumbo nucifera & Nelumbonaceae & lotus & Leaf \\
\hline Paeonia suffruticosa & Paeoniaceae & peony, mǔdān & Root \\
\hline Panax ginseng & Araliaceae & asian ginseng & Root \\
\hline Phellodendron amurense & Rutaceae & huang bai, cork tree & Bark \\
\hline Pinctada martensii & Pteriidae & pearl oyster & [Mollusk] \\
\hline Pinus tabuliformis & Pinaceae & chinese red pine & Wood, leaf \\
\hline Polygonatum offi cinale & Asparagaceae & solomon's seal & Root \\
\hline Polygonum cuspidatum & Polygonaceae & japanese knotweed & Root \\
\hline Polygonum multiflorum & Polygonaceae & chinese knotweed & Root \\
\hline Poria cocos & Polyporaceae & fu ling & [Mushroom] \\
\hline Prunus armeniaca & Rosaceae & apricot & Seed \\
\hline Rehmannia glutinosa & Phrymaceae & sheng di huang & Root \\
\hline Rhodiola rosea & Crassulaceae & goldenroot & Rhizome \\
\hline Salvia miltiorrhiza & Lamiaceae & chinese sage & Root \\
\hline Scutellaria baicalensis & Lamiaceae & baikal skullcap & Root \\
\hline Silybum marianum & Asteraceae & milk thistle & Seed \\
\hline Sophora flavescens & Fabaceae & korean cream pea & Root \\
\hline Tribulus terrestris & Zygophyllaceae & bai ji li, puncture vine & Fruit \\
\hline Tricholoma matsutake & Tricholomataceae & pine mushroom & [Mushroom] \\
\hline Vitis vinifera & Vitaceae & grape & Fruit, seed \\
\hline Zanthoxylum alatum & Rutaceae & prickly ash & Bark \\
\hline
\end{tabular}

not highly regulate the production and sale of personal care products. Still, cosmetic companies are subject to the Federal Food, Drug, and Cosmetic Act (FD\&C Act) and Fair Packaging and Labeling Act (FPLA). In general, cosmetics do not require FDA approval before they go on the market and the companies are responsible for product safety. The FD\&C Act prohibits the marketing of adulterated products that contain toxic substances or are unsanitary or misbranded products that have false or misleading labeling. The FPLA requires products to have an academic and government experts to review safety information on cosmetic ingredients. CIR experts have reviewed many natural extracts and their conclusions are published in the scientific literature (Antignac et al., 2011). The Consumer Commitment Code recommends the reporting of serious adverse events to the FDA, maintenance of safety substantiation files on products and ingredients, and making these safety files available to the FDA for inspection.

Another program managed by the Personal Care Product Council is the INCI system, which was created to ensure uniform labeling. This system uses Latin binomials and English words but differs greatly from IUPAC or CAS nomenclature. For medicinal plant extracts, the INCI name uses the Latin binomial, plant part, and indicates extraction method in the indexed definition (Table 2). Medicinal plant growers and processors therefore need to make correct identification of their plant material for labeling purposes using the appropriate genus and species rather than common names. Otherwise, the final product could be in violation of the FPLA if the plant is misidentified.

The FD\&C Act further stipulates that cosmetics companies cannot make claims that their products treat or prevent disease or otherwise affect the structure or any function of the body; otherwise, the product is considered a drug, which is subject to a different set of FDA regulations. There are a number of ingredients in personal care products that are regulated as over-the-counter (OTC) drugs including acne ingredients like benzoyl peroxide (FDA, 2010) and ultraviolet filters like avobenzone, titanium dioxide, and zinc oxide (FDA, 2011). The FDA monographs that include these molecules have specific requirements for allowable concentrations and testing that must be performed before a product can be marketed. Medicinal plant extracts fall outside of OTC regulations and therefore, companies must be prudent when making efficacy claims for these ingredients. The FDA does not recognize the term "cosmeceutical" and warns against any labeling to this effect.

The term "organic" is defined by the U.S. Department of Agriculture (USDA) through its National Organic Program (USDA, 2011) for food ingredients. Medicinal plants used for food that meet the requirements for organic production may be certified organic. The operations that produce the organic agricultural ingredients, the handlers of these agricultural ingredients, and the manufacturer of the final product (extract) must all be certified by a USDA-accredited organic certifying agent. A finished product (e.g., skin cream, shampoo, etc.) may receive organic certification based on the percentage of organic ingredients (excluding water and salt) as shown in Table 3 . The USDA has no authority over the production and labeling of cosmetics that are not made up of agricultural ingredients or do not make any claims to meeting USDA organic standards. Agricultural ingredients from around the world may be certified USDA organic by authorized third-party agents. In addition, products may 
Table 2. International Nomenclature for Cosmetic Ingredients (INCI) names for various ingredients made from the genus Vaccinium (Gottschalck and Bailey, 2010).

\begin{tabular}{|c|c|}
\hline INCI name & Description \\
\hline $\begin{array}{l}\text { Saccharomyces/vaccinium vitis-idaea } \\
\text { fruit ferment extract }\end{array}$ & $\begin{array}{l}\text { Extract of the product obtained by the fermentation of the fruit } \\
\text { of Vaccinium vitis-idaea by the microorganism, } \\
\text { Saccharomyces }\end{array}$ \\
\hline Vaccinium angustifolium extract & $\begin{array}{l}\text { Extract of the fruit of the blueberry, Vaccinium angustifolium, } \\
\text { Ericaceae }\end{array}$ \\
\hline Vaccinium angustifolium fruit juice & $\begin{array}{l}\text { Liquid expressed from the fruit of blueberry, Vaccinium } \\
\text { angustifolium, Ericaceae }\end{array}$ \\
\hline Vaccinium angustifolium leaf extract & $\begin{array}{l}\text { Extract of the leaves of blueberry, Vaccinium angustifolium, } \\
\text { Ericaceae }\end{array}$ \\
\hline Vaccinium & $\begin{array}{l}\text { Seeds obtained from the blueberry, Vaccinium angustifolium, } \\
\text { Ericaceae }\end{array}$ \\
\hline Vaccinium macrocarpon fruit powder & $\begin{array}{l}\text { Powder obtained from the dried, ground fruits of the cranberry, } \\
\text { Vaccinium macrocarpon, Ericaceae }\end{array}$ \\
\hline Vaccinium macrocarpon seed oil & $\begin{array}{l}\text { ssed from the seeds of the cranberry, Vaccinium } \\
\text { Ericaceae }\end{array}$ \\
\hline Vaccin & $\begin{array}{l}\text { Powder obtained from the dried, ground seeds of the cranberry, } \\
\text { Vaccinium macrocarpon, Ericaceae }\end{array}$ \\
\hline Vaccinium myrtillus bud extract & $\begin{array}{l}\text { Extract of the buds of the myrtle, Vaccinium myrtillus L., } \\
\text { Ericaceae }\end{array}$ \\
\hline Vaccinium myrtillus fruit/leaf extract & $\begin{array}{l}\text { Extract of the fruit and leaves of the myrtle, Vaccinium } \\
\text { myrtillus L., Ericaceae }\end{array}$ \\
\hline Vaccinium myrtillus stem extract & $\begin{array}{l}\text { Extract of the stems of the myrtle, Vaccinium myrtillus L., } \\
\text { Ericaceae }\end{array}$ \\
\hline Vacci & Extract of the berries of Vaccinium uliginosum L., Ericaceae \\
\hline Vaccinium & $\begin{array}{l}\text { Aqueous solution of the steam distillate obtained from the } \\
\text { fruit of the cowberry, Vaccinium vitis-idaea L., Ericaceae }\end{array}$ \\
\hline Vaccinium vitis-idaea leaf extract & $\begin{array}{l}\text { Extract of the leaves of the cowberry, Vaccinium vitis-idaea L., } \\
\text { Ericaceae }\end{array}$ \\
\hline
\end{tabular}

Table 3. List of requirements for USDA organic labeling.

\begin{tabular}{lclc}
\hline $\begin{array}{l}\text { Organic } \\
\text { ingredients }\end{array}$ & $\begin{array}{c}\text { USDA organic } \\
\text { seal }\end{array}$ & \multicolumn{1}{c}{ Label claim } & \multicolumn{1}{c}{ Other requirements } \\
\hline $100 \%$ & Yes & $100 \%$ organic & $\begin{array}{c}\text { Must display the certifying agent's name } \\
\text { and address } \\
\text { Must display the certifying agent's name } \\
\text { and address }\end{array}$ \\
$75 \%$ & Yes & Organic & $\begin{array}{c}\text { Made with organic } \\
\text { Cangredients } \\
\text { on the principle display panel } \\
\text { Can identify organic ingredients on } \\
\text { ingredient list }\end{array}$ \\
\hline
\end{tabular}

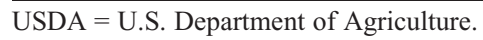

be certified by other private standards and be marketed to those private standards in the United States. These standards might include foreign organic standards, ecolabels, earth friendly, etc. (USDA, 2008).

Communicating efficacy is a delicate topic for personal care products considering the regulatory environment. Medicinal plants by definition may afford health-promoting properties including antioxidant, anti-inflammatory activity, sun protection, antimicrobial activity, or wound healing activity. However, the ability to communicate these activities on a cosmetic label is limited. Consumers or the FDA itself may challenge unsubstantiated label claims. Therefore, even if acceptable claims are used (e.g., "soothes the skin" instead of "reduced inflammation"), and the medicinal plant has been used for generations in traditional medicine, these claims should be substantiated by internal claims testing (clinical trials, in vitro assays, etc.), efficacy data provided by raw material suppliers, and an exhaustive literature search. The amount and nature of evidence collected to support a label claim is highly dependent on the claim itself and often the available resources. sure it conforms to the physical and analytical characteristics of the standard. Safety testing is performed on medicinal plant ingredients as well. To avoid adverse events, cosmetics companies perform in vitro testing to screen for cell damage in skin cell cultures or irritation in skin construct models. Some companies may still perform animal testing. However, most companies are developing alternatives since the European Commission Cosmetics Directive (European Commission, 2011) implemented an animal testing ban on finished cosmetic products and ingredients. Some forms of animal testing are still being phased out such as repeated-dose toxicity, reproductive toxicity, and toxicokinetics. The Human Repeat Insult Patch Testing (Henderson and Riley, 1944) is one method to predict the possibility of skin sensitization reactions in humans. An in-depth review of this and other safety testing for botanical ingredients in cosmetics can be found in Antignac et al. (2011).

If a medicinal plant ingredient is found to be safe and stable, it can move on to the formulation phase where it is added to a cosmetic formula and re-tested for the same parameters, safety, stability, etc. In addition, it is tested for efficacy to make label and marketing claims. Cosmetic products may target photo damage (Balskus and Walsh, 2010), hyperpigmentation (Huang et al., 2011), dandruff (Wuthi-Udomlert et al., 2011), acne (Lee et al., 2011), oily skin (Vogelgesang et al., 2011), aging (Manosroi et al., 2011), or rosacea (Emer et al., 2011), to name a few. After all testing is complete, a formula is scaled up to industrial production, filled into packaging, again tested for quality assurance, and shipped to market for sale.

\section{CONCLUSIONS}

Sourcing medicinal plants for use in cosmetics is not as straightforward as other conventional cosmetic ingredients where the supply chain and material composition are relatively well defined. Responsibly sourcing medicinal plant materials is even more complicated where sustainability ethics-issues of economic development, social equity, and environmental protection-must be considered. Before the mid-1980s, the concept of sustainability was not widely addressed. Industrialized nations were becoming concerned with global problems like population growth, consumer demand on resources, global warming, deforestation, species loss, and pollution. However, developing nations were more concerned with their own economic development than environmental issues. In 1987, the United Nations published "Our Common Future," the results of a study on the relationship between economic development and environmental concerns (Brundtland and Khalid, 1987). This report, commonly known as the "Brundtland Report," addresses the interdependence of nations, industrialized and developing, and laid the framework for the 1992 Rio Convention on Biological Diversity. It provides a simple definition of sustainable 


\section{BOX 1. EXAMPLES OF FAIR TRADE AND SUSTAINABLE SOURCING PARTNERSHIPS.}

Case 1. A French cosmetics company initiated successful fair trade relationships in Vietnam and Madagascar (Arguelles, 2009). In the Mekong Delta region of Vietnam, vu sua fruit (Chysophyllum cainito) is the main source of revenue for the village of Vin Kim. Through a fair trade agreement, vu sua is harvested and provided to the cosmetics company. The cosmetics company pays a premium price for the fruit, which financed the building of a school for local children. In Madagascar, the company creates job opportunities through the harvesting of Centella asiatica, Vernonia appendiculata (Ambiaty), and the extraction of Cedrelopsis grevei (Katafray) bark. A fair trade policy assures $5 \%$ all income received is invested in local community projects like supplying drinking water to the villagers and renovating the village's school. In addition, the company pledged to replant 10,000 Cedrelopsis grevei trees in that region.

Case 2. Development of new palm oil plantations converts large areas of rich tropical forests and threatens the biodiversity in these ecosystems. This is especially problematic in Southeast Asia (Koh and Wilcove, 2007). Cosmetic and food companies receive substantial criticism from environmental groups for being the largest users of palm oil. Recent campaigns from Greenpeace targeted Unilever and Nestle (Greenpeace, 2009). The Roundtable on Sustainable Palm Oil (RSPO) was founded in 2003 in cooperation with the World Wildlife Fund as an industry-led initiative to address these concerns. The RSPO sets standards for sustainable palm oil production with criteria that include social, environmental, and economic good practices. Today, most of the major personal care companies have initiatives to purchase all of their palm oil and derivatives from certified sustainable sources.

Case 3. A Japanese cosmetics company partnered with a forestry company initially to produce cosmetic ingredients through plant tissue culture. However, the relationship expanded into an initiative to preserve biodiversity and increase yields of horticultural crops when they discovered a stress-induced fatty acid compound with a stimulatory effect on flower initiation and rhizogenesis in cuttings (Yamaguchi et al., 2001). Through this research, they successfully propagated Somei-yoshino cherry trees and Camellia sasanqua trees at Ankokuron Temple in Kamakura city that were over 300 years old and in danger of dying because of decay. The next phase of research involves testing and developing this compound for flower initiation control in fruit trees. If successful, it may be used to boost the yields of horticultural crops that are declining as a result of global climate change.

development: "Humanity has the ability to make development sustainable to ensure that it meets the needs of the present without compromising the ability of future generations to meet their own needs."

The report points out that industry is central to the economies of modern societies. Industry provides products that support contemporary living. It extracts materials from the natural resource base and inserts both products and pollution into the human environment. It has the power to enhance or degrade the environment; it invariably does both (Brundtland and Khalid, 1987). The Convention on Biological Diversity states that the sustainable use of biodiversity will lead to its conservation, which points out the positive role that responsible private companies may have. Large cosmetic companies, generating $\$ 176.18$ billion of sales in 2010 (Weil, 2011), have considerable power to create positive change at a global scale. This power does not only come from large sweeping corporate policies on sustainability, but also from the small choices made on a daily basis by individuals. Certainly, many of these companies have already made significant progress toward sustainable development, especially in the area of sourcing sustainable raw materials. In the end, progress toward sustainability is incremental. With careful management, cosmetic companies can offer innovative beauty products that enhance the standard of living while conserving natural resources, promoting economic development for the poor, and protecting environmental resources.

\section{Literature Cited}

Achten, W.M., P. Vandenbempt, J. Almeida, E. Mathijs, and B. Muys. 2010. Life cycle assessment of a palm oil system with simultaneous production of biodiesel and cooking oil in Cameroon. Environ. Sci. Technol. 44:48094815.

Antignac, E., G.J. Nohynek, T. Re, J. Clouzeau, and H. Toutain. 2011. Safety of botanical ingredients in personal care products/cosmetics. Food Chem. Toxicol. 49:324-341.

Arguelles, A. 2009. Clarins makes the world go round. Vanity Fair. 15 Dec. 2009.

Assinewe, V.A., B.R. Baum, D. Gagnon, and J.T. Arnason. 2003. Phytochemistry of wild populations of Panax quinquefolius L. (North American ginseng). J. Agr. Food Chem. 51:4549-4553.

Balskus, E.P. and C.T. Walsh. 2010. The genetic and molecular basis for sunscreen biosynthesis in cyanobacteria. Science 329:1653-1656.

Brundtland, G.H. and M. Khalid, (eds.). 1987. Our common future. Report of the World Commission on Environment and Development. United Nations, Nairobi.

De Silva, T. 1997. Industrial utilisation of medicinal plants in developing countries, p. 34. In: FAO. Medicinal plants for forest conservation and healthcare. Non-wood forest products 11 . Food and Agriculture Organization of the United Nations, Rome, Italy.
Emer, J., H. Waldorf, and D. Berson. 2011. Botanicals and anti-inflammatories: Natural ingredients for rosacea. Semin. Cutan. Med. Surg. 30: 148-155.

European Commission. 2011. Cosmetics directive. 31 Oct. 2011. <http://ec.europa.eu/consumers/ sectors/cosmetics/animal-testing/index_en.htm>.

Fitzherbert, E.B., M.J. Struebig, A. Morel, F Danielsen, C.A. Brühl, P.F. Donald, and B. Phalan. 2008. How will oil palm expansion affect biodiversity? Trends Ecol. Evol. 23:538545.

Fong, H.H.S., J.E. Simon, and J. Regalado. 2003. WHO guidelines on good agricultural and collection practices (GACP) for medicinal plants. World Health Organization, Geneva, Switzerland.

Food and Agriculture Organization of the United Nations. 2004. Trade in medicinal plants. Workshop on Medicinal Plants, 22-26 July 2004, Bangalore, India.

Food and Drug Administration. 2010. Classification of benzoyl peroxide as safe and effective and revision of labeling to drug facts format; topical acne drug products for over-the-counter human use; final rule. Fed. Regist. 75:97679777.

Food and Drug Administration. 2011. Labeling and effectiveness testing; sunscreen drug products for over-the-counter human use. Fed. Regist. 76:35620-35665.

Gottschalck, T.E. and J.E. Bailey. 2010. International cosmetic ingredient dictionary and handbook. 13th Ed. The Personal Care Products Council, Washington, DC.

Greenpeace. 2009. Public pressure for Indonesia's forests works, ask Unilever. <http://www. greenpeace.org/international/en/campaigns/ forests/asia-pacific/dove-palmoil-action/>.

Greenpeace. 2011. Palm oil. 31 Oct. 2011.<http:// www.greenpeace.org/eastasia/campaigns/forests/ problems/palm-oil/s

Henderson, C.R. and E.C. Riley. 1944. Certain statistical considerations in patch testing. J. Invest. Dermatol. 6:227-232.

Huang, H.C., S.H. Chiu, and T.M. Chang. 2011. Inhibitory effect of [6]-Gingerol on melanogenesis in B16F10 melanoma cells and a possible mechanism of action. Biosci. Biotechnol. Biochem. 75:1067-1072.

Koh, L.P. and D.S. Wilcove. 2007. Cashing in palm oil for conservation. Nature 448:993-994.

Lee, H.E., J.Y. Ko, Y.H. Kim, S.R. Yoo, S.H. Moon, N.I. Kim, C.W. Park, J.H. Kim, H.J. Koh, W.S. Park, and Y.S. Ro. 2011. A doubleblind randomized controlled comparison of APDDR-0901, a novel cosmeceutical formulation, and $0.1 \%$ adapalene gel in the treatment of mild-to-moderate acne vulgaris. Eur. J. Dermatol. 21:959-965.

Mak, C.Y. and C.S. Mok. 2011. Molecular identification of Lodoicea maldivica (coco de mer) seeds. Chin. Med. 6:34.

Manosroi, A., P. Jantrawut, T. Akihisa, W. Manosroi, and J. Manosroi. 2011. In vitro and in vivo skin anti-aging evaluation of gel containing niosomes loaded with a semi-purified fraction containing gallic acid from Terminalia chebula galls. Pharm. Biol. 49:1190-1203.

Pereira, A.M., S.F. Amui, B.W. Bertoni, R.M Moraes, and S.C. França. 2003. Micropropagation of Anemopaegma arvense: Conservation of an endangered medicinal plant. Planta Med. 69:571-573

Philippe, M., B. Didillon, and L. Gilbert. 2012 Industrial commitment to green and sustainable chemistry: Using renewable materials \& developing eco-friendly processes and ingredients in cosmetics. Green Chem. 14:952-956. 
RSPO Executive Board. 2007a. RSPO principles and criteria for sustainable palm oil production. Roundtable on Sustainable Palm Oil, Kuala Lumpur.

RSPO Executive Board. 2007b. Final RSPO Certification Systems document. Roundtable on Sustainable Palm Oil, Kuala Lumpur.

Secretariat of the Convention on Biological Diversity. 2011. The Nagoya protocol on access to genetic resources and the fair and equitable sharing of benefits arising from their utilization: Text and annex. Secretariat of the Convention on Biological Diversity, United Nations Environmental Programme, Montreal, Ontario, Canada.

Shi, J.Y., X.F. Yuan, H.R. Lin, Y.Q. Yang, and Z.Y. Li. 2011. Differences in soil properties and bacterial communities between the rhizosphere and bulk soil and among different production areas of the medicinal plant Fritillaria thunbergii. Intl. J. Mol. Sci. 12:37703785.

State Drug Administration, P.R. China. 2002. Good agricultural practice for Chinese crude drugs (interim). Order No. 32 of SDA. Beijing, China.

Tabone, M.D., J.J. Cregg, E.J. Beckman, and A.E. Landis. 2010. Sustainability metrics: Life cycle assessment and green design in polymers. Environ. Sci. Technol. 44:8264-8269.
Thongbaia, P., T. Kozaib, and K. Ohyamaa. 2010. $\mathrm{CO}_{2}$ and air circulation effects on photosynthesis and transpiration of tomato seedlings. Sci. Hort. 126:338-344.

Timilsina, G. and A. Shrestha. 2010. Biofuels: Markets, targets, and impacts. Policy Research Working Paper No. 5364. World Bank, Washington, DC.

Timilsina, G.R., J.C. Beghin, D. van der Mensbrugghe, and S. Mevel. 2010. Economic and environmental impacts of biofuels. Policy Research Working Paper No. WPS 5513. World Bank, Washington, DC.

United Nations. 1992. Convention on biological diversity. United Nations, Rio de Janeiro, Brazil.

United States Department of Agriculture. 2008 National organic program: Cosmetics, body care products, and personal care products. U.S. Department of Agriculture, Washington, DC.

United States Department of Agriculture. 2011. National organic program. 31 Oct. 2011. $<$ http: //www.ams.usda.gov/AMSv1.0/nop>.

Verhoeven, J.T. and T.L. Setter. 2010. Agricultural use of wetlands: Opportunities and limitations. Ann. Bot. (Lond.) 105:155-163.

Vogelgesang, B., N. Abdul-Malak, C. Reymermier, C. Altobelli, and J. Saget. 2011. On the effects of a plant extract of Orthosiphon stamineus on sebum-related skin imperfections. Intl. J. Cosmet. Sci. 33:44-52.

Weil, J. (ed.). Beauty's top 100: The top 25. Beauty Inc. 12 Aug. 2011.

World Bank. 2011a. Food price watch. 14 Apr World Bank, Washington, DC.

World Bank. 2011b. Global commodities markets commodity price data. 31 Oct. 2011. <http:// www.worldbank.org/prospects/commodities $>$.

World Bank. 2011c. Global economic prospects June 2011: Subject annex. World Bank, Washington, DC.

Wuthi-Udomlert, M., P. Chotipatoomwan, S. Panyadee, and W. Gritsanapan. 2011. Inhibitory effect of formulated lemongrass shampoo on Malassezia furfur: A yeast associated with dandruff. Southeast Asian J. Trop. Med. Public Health 42:363-369.

Yamaguchi, S., M. Yokoyama, T. Iida, M. Okai, O. Tanaka, and A. Takimoto. 2001. Identification of a component that induces flowering of Lemna among the reaction products of alphaketol linolenic acid (FIF) and norepinephrine. Plant Cell Physiol. 42:1201-1209.

Zinoviev, S., F. Müller-Langer, P. Das, N. Bertero, P. Fornasiero, M. Kaltschmitt, G. Centi, and S. Miertus. 2010. Next-generation biofuels: Survey of emerging technologies and sustainability issues. ChemSusChem 3:1106-1133. 